\title{
Evidence of apple blotch resistance in wild apple germplasm (Malus spp.) accessions
}

\author{
Thomas Wöhner (D) - Ofere Francis Emeriewen • \\ Monika Höfer
}

Accepted: 10 November 2020 /Published online: 27 November 2020

(C) The Author(s) 2020

\begin{abstract}
Diplocarpon coronariae causes apple blotch, which results in significant economic losses. Resistance to apple blotch in commercial apple cultivars has not been reported in recent literature. The Malus germplasm collection from the Fruit Genebank of the Julius Kühn-Institut that is maintained in Dresden, Germany consists of 516 accessions of about 49 Malus species. This apple gene pool was evaluated for resistance to Diplocarpon coronariae. A four-year field survey was subsequently followed by artificial inoculation of field-selected accessions. Fifteen accessions that represent nine different species and hybrids were confirmed to be highly resistant following a repeated inoculation assay in the laboratory. The results from this investigation is of high interest to breeders for future apple breeding programmes and investigations of resistance to Diplocarpon coronariae.
\end{abstract}

Keywords Diplocarpon coronariae $\cdot$ Malus $\cdot$ Wild species $\cdot$ Germplasm $\cdot$ Resistance $\cdot$ Marssonina coronaria

The genus Malus Mill belonging to the Rosaceae family of plants, is subdivided into six sections including

T. Wöhner $(\bowtie) \cdot$ O. F. Emeriewen • . Höfer

Julius Kühn-Institute, Federal Research Centre for Cultivated Plants, Institute for Breeding Research on Fruit Crops, Pillnitzer Platz 3a, 01326 Dresden, Germany e-mail: thomas.woehner@julius-kuehn.de between 25 to 47 species, depending on the taxonomic classification (Robinson et al. 2001, Forsline et al. 2003, GRIN, https://npgsweb.ars-grin.gov). The domesticated apple (Malus $\times$ domestica Borkh.), a prominent member of this genus, is one of the most important fruit crops cultivated in the temperate zone (Hanke et al. 2020). The largest apple producers in the world are China, USA and Poland. Although, apple production for 2018 was 86.1 MMT (FAOSTAT 2020), several diseases threaten its production. One of such diseases is apple blotch, caused by the fungus Diplocarpon coronariae ((Ellis and Davis) Wöhner and Rossmann) previously designated as Marssonina coronaria (Crous et al. 2020).

The disease has increasingly caused economic losses in apple cultivation in China and in organic cultivation orchards in Europe (Wöhner and Emeriewen 2019). Apple blotches appear on leaves between June and August followed by premature defoliation of the tree crown before fruit harvest. Fruit blotches (Sutton et al. 2014) also cause several losses but are less frequent. Different factors and stages of the fungus lead to typical apple blotch symptoms and occurrence worldwide (Reviewed in Wöhner and Emeriewen 2019). Disease control by fungicide application has been shown to protect commercial apple orchards against apple blotch (Dang et al. 2017; Sharma et al. 2018).

Breeding for disease resistance would be another possibility to manage the disease (Aldwinckle et al. 1997), but unfortunately, most apple cultivars are susceptible to the disease (Wöhner et al. 2019). Nevertheless, Yin et al. (2013a) described sources for resistance in wild apple accessions. However, there are no studies 
describing apple blotch resistance/susceptibility in a diverse Malus germplasm over several years.

In the present study, we assessed the field occurrence of $D$. coronariae by the assessing leaf blotch symptoms in the Malus germplasm collection of the JKI Fruit Genebank between 2014 and 2018. The collection of the Julius Kühn-Institut, Institute for Breeding Research on Fruit Crops consists of 516 accessions representing 49 species and several Malus hybrids of the genus Malus (Höfer et al. 2014). The ages of the assessed trees ranged from 9 to 15 years old. The collection was originally grafted on the rootstock 'Bittenfelder Sämling' in 1998 and planted in 1999. However, several trees were lost due to disease outbreaks, hence were replanted and therefore the trees consist of different ages. The trees were not sprayed with any disease protective agents during the evaluation period.

Apple blotch, cause by $D$. coronariae, was first confirmed in the experimental field of the JKI in 2014 (Wöhner 2015). The assessment of typical symptoms (Fig. 1a) was conducted in September each year (except 2017). Crown defoliation (Fig. 1b) was scored between 2015 and 2018 for trees of each accession. Up to four trees per accession were assessed for crown defoliation, although only one and two trees were assessed for several accession (Fig. S1). The disease incidence was assessed for each accession that showed symptoms of $D$. coronariae as follows: no symptom in all four years $=$ no incidence; symptoms in only one year = low incidence; symptoms in two years = intermediate incidence; symptoms in three years = high incidence; and symptoms in all four years = very high incidence. The percentage incidence of apple blotch was calculated by dividing the number of incidence from four years of evaluation by the number of times evaluations were carried out in the four-year period, and multiplied by 100 . To confirm the results of the field observations, we inoculated up to six leaves of the same age of 136 accessions from the Malus wild species collection that showed no disease symptoms in the field, in two separate experiments. The $M$. $\times$ domestica cv. 'Golden Delicious', which is susceptible to the disease, was used as positive control in the laboratory assay with spores of $D$. coronariae. Briefly, symptomatic leaves collected from the field were used to prepare conidia suspension by squeezing the leaves in a 51 beaker containing tap water and subsequently filtering through a thin metal filter to separate the obtained solution from leaf debris. The concentration of the conidia was determined with a haemocytometer (Thoma, Germany). Finally Tween $20(0.01 \%)$ was added to the final inoculum suspension. Conidia concentration of $6 \times 10^{5}$ per millilitre and $79-90 \%$ conidial germination was obtained on water agar after $24 \mathrm{~h}$, and used for inoculation. Detached leaves of the 136 accessions were sprayed three times (Wöhner et al. 2019) with inoculum on the abaxial and adaxial side and kept humid over the infection period at a temperature of $24{ }^{\circ} \mathrm{C}, 12 \mathrm{~h}$ diffuse light and $12 \mathrm{~h}$ of darkness. After inoculation, petri dishes were sealed with parafilm. Symptom assessment and diseased leaf area measurement using the leaf doctor software (Pethybridge and Nelson 2015) was carried out 14 days post inoculation. The percentage of mean diseased leaf area was calculated. Statistical analyses included Shapiro-Wilk test on normal distribution of the data. The Mann Whitney $U$ test procedure was performed to analyse the data for significant differences between highly resistant accessions (mean disease leaf area $<10 \%$ ) and the percentage of mean diseased leaf area of susceptible control $M$. $\times$ domestica cv. 'Golden Delicious'.

In the field observations (Fig. 2a), 183 accessions showed no disease symptom. The disease incidence of 143 accessions was classed as low, 101 accessions were classified as intermediate, and in 65 accessions disease incidence was classified as high. Twenty-four accessions showed symptoms in all four years of field observation and hence their disease incidence was classified as very high (Fig. 2a). The frequency of the disease incidence for each year and the average incidence are outlined in Fig. 2b. The mean number of accessions with typical symptoms of $D$. coronariae was $159(\mathrm{SD} \pm 84.4)$ whilst the mean number of accessions without symptoms was $285(\mathrm{SD} \pm 110)$.

Table 1 shows the percentage incidence of apple blotch symptoms per Malus species. Twenty-three of the 49 species and Malus hybrids evaluated were represented by a number of $\geq 5$ accessions and therefore selected for calculation, whereas species with $n<5$ accessions were excluded from the calculation. None of the 6 accessions of $M$. sikkimensis and 18 accessions of $M$. sieboldii expressed symptoms of $D$. coronariae between 2014 and 2018. Between $59.6 \%$ and $71.3 \%$ of the accessions from the species $M$. prunifolia, M. floribunda, M. $\times$ domestica, M. asiatica and M. sieversii 


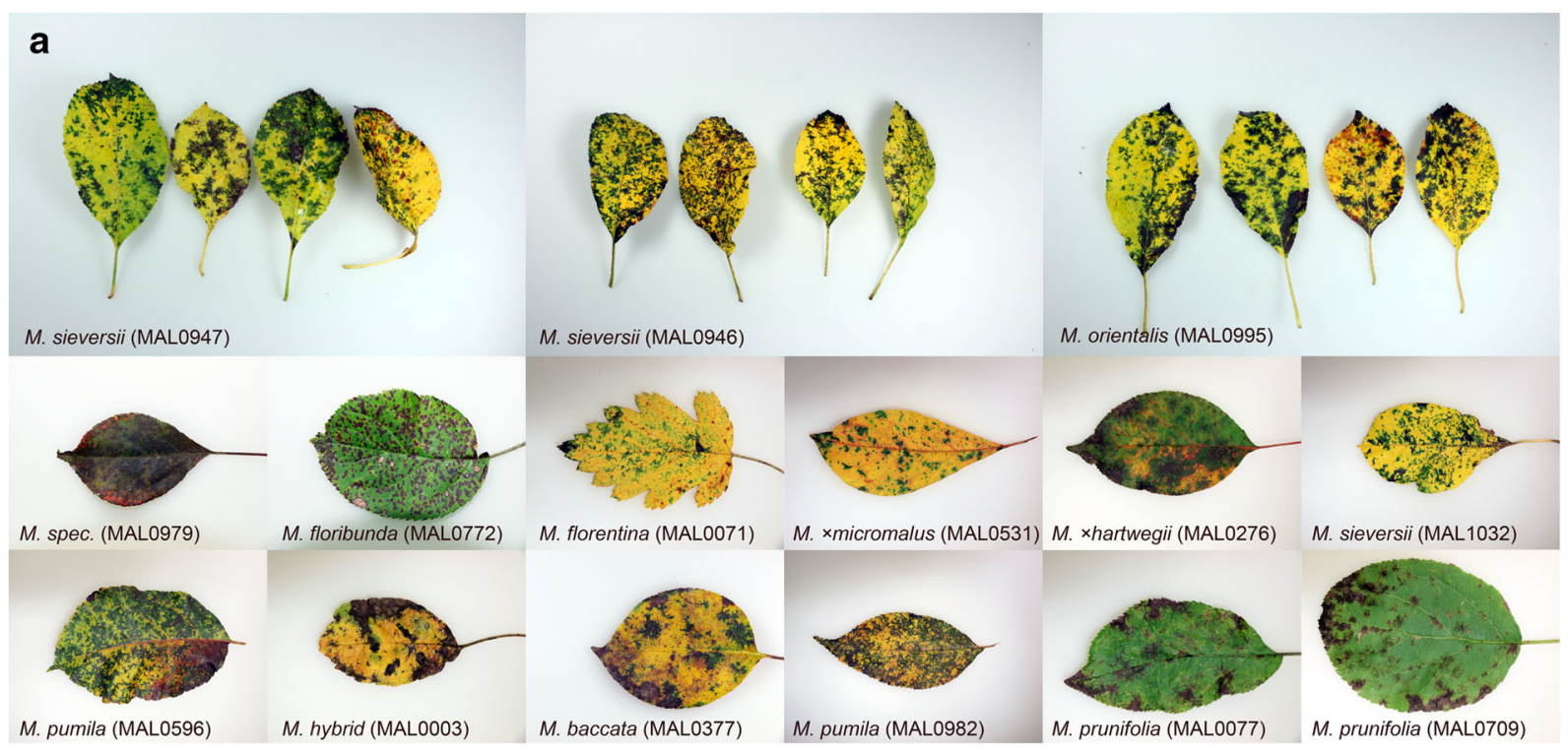

b
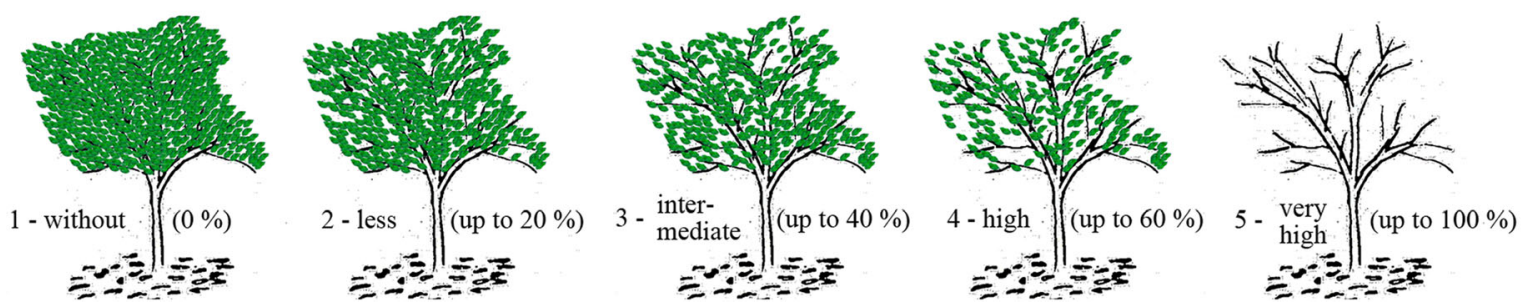

Fig. 1 (a) D. coronariae symptoms on accessions of Malus wild species in the gene bank of the Julius Kühn - Institut in Dresden. To avoid mistakes, a scab symptomatic leaf of $M$. prunifolia

developed apple blotch symptoms for the evaluated period.

For the crown defoliation assessment, an overall mean defoliation score of $2.16(\mathrm{SD} \pm 0.81)$ was obtained for all accessions in the field plot. The lowest mean defoliation score was observed for M. × heterophylla (accession MAL0390) and the highest for three accessions of $M$. pumila. Figure 3 shows parts of the results of crown defoliation assessment for Malus wildspecies with accessions $n>5$.

Results of the two detached leaf experiments showed that several of the 136 accessions, which developed no symptoms in the field observation, developed disease. Only 15 accessions had less than $10 \%$ mean diseased leaf (Table 2). Of these, 10 accessions developed no symptoms of $D$. coronariae in both experiments, whereas the other five accessions developed typical symptoms in one or both performed experiments. Figure 4 shows
(MAL0709) was added to the figure and clearly shows differences between the two leaf diseases. (b) Rating scale for estimating the defoliation of tree crowns in field assessments

M. prunifolia accession MAL0175 (without symptoms) and M. domestica cultivar 'Golden Delicious' (with symptoms) following artificial inoculation, A correlation analyses performed to compare the mean percentage diseased leaf area from all accessions of both experiments showed a correlation coefficient of $\rho=0.71$ (Fig. 5). The susceptible control 'Golden Delicious' developed $90.3 \%$ diseased leaf area, and was significantly different $(p<0.01)$ from other accessions.

Diplocarpon coronariae, a major disease pathogen of apple in China, is increasing in significance in European organic production (Wöhner and Emeriewen 2019). A major impact of apple blotch disease is premature defoliation of the tree crown before fruit harvest. Massive defoliation over several years weakens the physiological balance of the host, leading to a reduced vigour and decreased yields (Yin et al. 2013a). Screening for the disease and the subsequent identification of 
Fig. 2 (a) Number of Malus accessions with different frequencies of $D$. coronariae during a time interval from 2014 to 2018 (without 2017). (b) averaged number of Malus accessions with present and absent symptoms of

D. coronariae for each evaluation year a

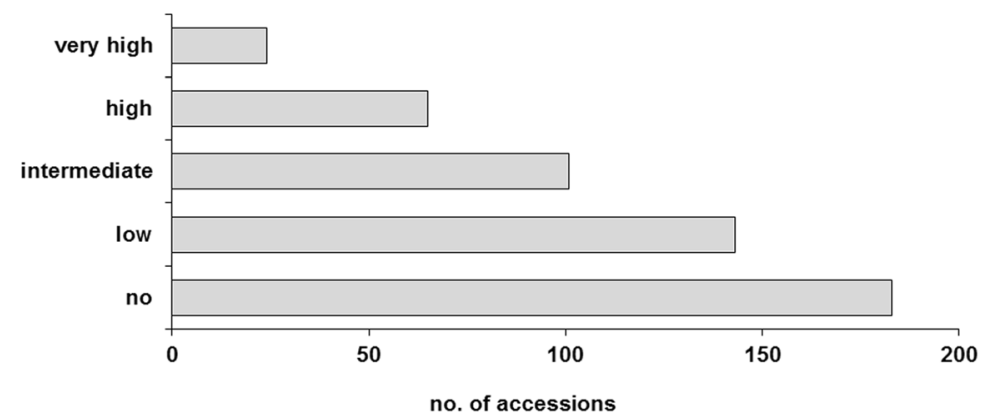

b

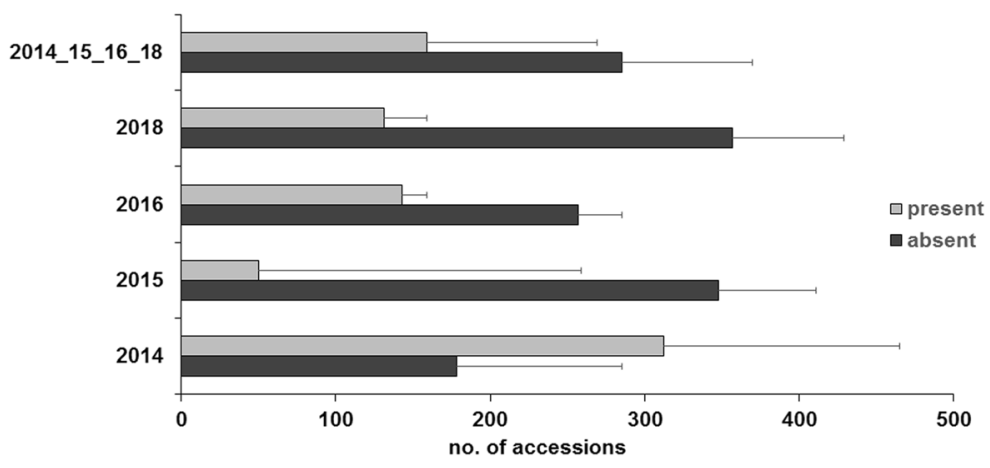

resistance donors will be crucial for future apple blotch resistance breeding programs. Assessment of large germplasm collections can be performed through field surveys, laboratory assays or with the use of molecular markers, if available ( $\mathrm{Li}$ et al. 2019). In this study, we performed a four-year field screening for resistance/ susceptibility to apple blotch in more diverse Malus germplasm than previously reported (Yin et al. 2013a; Li et al. 2012). Following field observations, we identified and selected 136 accessions for further testing. The field observations indicated that disease spreads within the plot and that disease incidence increased from west to the east in the field plot (Fig. S2). This is not surprising given the main wind direction in Dresden-Pillnitz; Germany is from west to east (Surke et al. 2013). Precise determination of resistance/susceptibility to apple blotch is essential for the identification of resistance donors and hence, a detached leaf bioassay is recommended to confirm results from the field screening. Detached leaf inoculation with spores of the pathogen allowed for the identification of 15 highly resistant accessions, a sharp reduction of the number of accessions thought to be resistant from field observation. The discrepancy between field and laboratory observations could be due to optimal conditions during pathogenesis in the laboratory assay and low infection pressure or unsuitable conditions in the field (Wöhner and Emeriewen 2019). Moreover, artificial inoculations of plants with causative pathogens usually overestimate susceptibility, nevertheless, is the usual practice in determining resistance/ susceptibility to plant pathogens (Peil et al. 2020; Kellerhals et al. 2012). However, it is important for future work in apple blotch resistance/susceptibility screening, to develop an automated field phenotyping system such as reported for other apple pathogens and plant species (Wang et al. 2017; Stewart and McDonald 2014; Jarolmasjed et al. 2019).

A variability of susceptible and resistant reactions to D. coronariae was observed in this study. Plant susceptible reactions are responses in which infection and spread of the disease occur, producing varying amounts of damage (Dayton et al. 1983). Typical susceptible reactions were observed both in field and laboratory experiments. The multiplication of the pathogen due to the development of acervuli and the spread of the pathogen over the whole leaf induces chlorosis and diseased leaf area. Thus, the measurement of diseased leaf area as performed in this study could prove suitable for 
Table 1 Percentage of incidence of apple blotch per evaluated Malus species from 2014 to 2018 (without 2017), $n>5$

\begin{tabular}{|c|c|c|c|c|}
\hline Malus species & No. of accessions & $\begin{array}{l}\text { No. of observations } \\
\text { within } 4 \text { years }{ }^{\mathrm{a}}\end{array}$ & $\begin{array}{l}\text { Incidence of } \\
\text { apple blotch }^{\mathrm{b}}\end{array}$ & $\begin{array}{l}\text { Percentage incidence of apple } \\
\text { blotch from evaluations }{ }^{\mathrm{c}}\end{array}$ \\
\hline Malus sikkimensis & 6 & 24 & 0 & 0.0 \\
\hline Malus sieboldii & 18 & 72 & 0 & 0.0 \\
\hline Malus hupehensis & 7 & 28 & 1 & 3.6 \\
\hline Malus coronaria & 9 & 36 & 2 & 5.6 \\
\hline Malus sargenti & 10 & 32 & 2 & 6.3 \\
\hline Malus sylvestris & 38 & 126 & 8 & 6.3 \\
\hline Malus $\times$ zumi & 8 & 32 & 3 & 9.4 \\
\hline Malus ioensis & 5 & 20 & 2 & 10.0 \\
\hline Malus fusca & 5 & 17 & 2 & 11.8 \\
\hline Malus baccata & 50 & 200 & 32 & 16.0 \\
\hline Malus toringoides & 5 & 20 & 4 & 20.0 \\
\hline Malus komarovii & 6 & 24 & 6 & 25.0 \\
\hline Malus spectabilis & 8 & 32 & 10 & 31.3 \\
\hline Malus $\times$ robusta & 6 & 24 & 8 & 33.3 \\
\hline Malus hybr. & 48 & 182 & 61 & 33.5 \\
\hline Malus $\times$ moerlandsii & 5 & 20 & 7 & 35.0 \\
\hline Malus $\times$ purpurea & 7 & 26 & 12 & 46.2 \\
\hline Malus orientalis & 11 & 43 & 20 & 46.5 \\
\hline Malus prunifolia & 49 & 188 & 112 & 59.6 \\
\hline Malus floribunda & 7 & 28 & 17 & 60.7 \\
\hline Malus $\times$ domestica & 34 & 127 & 84 & 66.1 \\
\hline Malus asiatica & 5 & 15 & 10 & 66.7 \\
\hline Malus sieversii & 109 & 237 & 169 & 71.3 \\
\hline
\end{tabular}

${ }^{a}$ Number of observation for each accession per species. Discrepancies in the number of accessions and observations is a result of loss of genotypes due to other pathogens in the field

${ }^{\mathrm{b}}$ Number of apple blotch incidence per observation

${ }^{\mathrm{c}}$ The percentage incidence of apple blotch was calculated by dividing the number of incidence from four years of evaluation by the number of times evaluations were carried out in the four-year period, and multiplied by 100

identification of resistance trait to D. coronariae. However, both characters should be strongly correlated..

Disease resistance or plant defense mechanisms against fungal diseases can be classified as constitutive (passive) or inducible (active) (Prell and Day 2001). Both mechanisms aim to reduce the extent of pathogen invasion and include structural and chemical factors (Prell and Day 2001). Therefore, future investigation of the 15 highly resistant accessions should include microscopic investigation after inoculation to determine whether spores of $D$. coronariae will develop germ tubes and if structural factors of the host inhibit further spread of the pathogen in the host tissues. Induced resistance can only be observed after the initiation of infection by the fungal pathogen (post-infectional or active defense). Active responses are cell or tissue responses that limit the severity of infection. Those responses are often seen in single cells (appositions or papillae) or on the tissue level (zone of barrier cells that separates infected cells from healthy tissue). Both interfere with fungal growth by: 1) limiting the translocation of water and nutrition out and toxins or enzymes into the plant cells, 2) producing plant cell walls that are more resistant to fungal penetration, and 3) impending fungal development allowing phytoalexins to reach effective levels. However, these defense mechanisms underlie genetic factors. In addition, major resistance genes against fungal diseases prevent the formation of sporulating lesions, whereas minor gene resistance conditions induce more subtle changes 


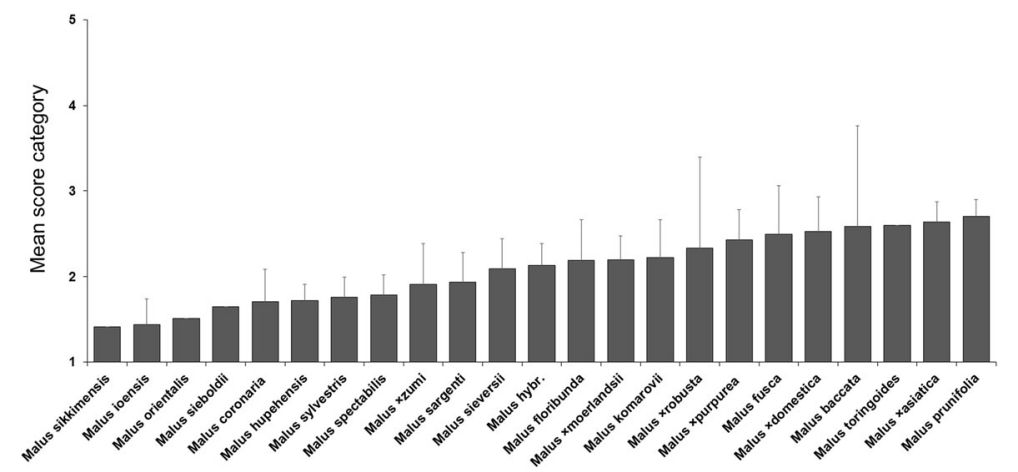

Fig. 3 Mean crown defoliation of evaluated Malus species from 2014 to 2018 (without 2017). At least $n \geq 5$ per species were evaluated for four years. Accessions without defoliation $(0 \%)$ were scored - 1, less defoliation (up to $20 \%$ ) -2 , intermediate (up to
$40 \%$ ) -3 , high (up to $60 \%$ ), very high (up to $100 \%$ ). The mean of evaluated accessions was calculated per species. The error bars indicate the standard deviation for each species

M. sieversii, the primary progenitor of the cultivated apple, when studying the expressions of marker genes for salicylic acid (SA), jasmonic acid (JA) and ethylene (ET) triggered defense pathways. Due to the hemibiotrophic lifestyle of $D$. coronariae, observed incompatible interactions of early defense responses were more associated with SA-signaling and ROS accumulation (biotrophic stage) followed by JA-mediated defense at later infection stages; typical for necrotrophic stage (Yin et al. 2013b). Similarly, resistance related proteins have recently been identified

Table 2 Malus wild species accession of the Julius Kühn-Institut collection resistant to apple blotch

\begin{tabular}{|c|c|c|c|c|c|c|}
\hline \multirow[t]{2}{*}{ Acc no. } & \multirow[t]{2}{*}{ Malus species } & \multirow{2}{*}{$\begin{array}{l}\% \text { mean disease } \\
\text { leaf area }\end{array}$} & \multirow[t]{2}{*}{$\mathrm{SD}$} & \multicolumn{2}{|c|}{ Apple blotch leaf symptoms } & \multirow{2}{*}{$\begin{array}{l}\text { Mann Whitney U significance (p) } \\
\text { compared to 'Golden Delicious' }\end{array}$} \\
\hline & & & & Exp. I & Exp. II & \\
\hline MAL0419 & baccata & 0.0 & 0.0 & - & - & $<0.01$ \\
\hline MAL0778 & baccata & 0.1 & 0.3 & & & $<0.01$ \\
\hline MAL0364 & $\times$ zumi & 0.7 & 1.3 & & & $<0.01$ \\
\hline MAL0302 & $\times$ platycarpa & 2.1 & 3.5 & & & $<0.01$ \\
\hline MAL1144 & 'Evereste' & 2.3 & 3.0 & & & $<0.01$ \\
\hline MAL0969 & sargenti & 2.5 & 3.6 & & & $<0.01$ \\
\hline MAL0175 & prunifolia & 3.1 & 3.9 & & & $<0.01$ \\
\hline MAL0722 & sieboldii & 5.4 & 10.3 & & & $<0.01$ \\
\hline MAL0278 & $\times$ sublobata & 8.0 & 6.4 & & & $<0.01$ \\
\hline MAL0547 & $\times$ sublobata & 8.8 & 16.4 & & & $<0.01$ \\
\hline MAL1020 & baccata & 7.9 & 8.4 & - & + & $<0.01$ \\
\hline MAL0710 & sargenti & 8.9 & 6.9 & & & $<0.01$ \\
\hline MAL1018 & baccata & 6.2 & 6.6 & + & - & $<0.01$ \\
\hline MAL1005 & transitoria $\times$ floribunda & 4.7 & 3.2 & + & + & $<0.01$ \\
\hline APF0239 & × domestica cv. 'Golden Delicious' & 90.3 & 21.9 & + & & - \\
\hline
\end{tabular}

Mann Whitney U significance was calculated according to https://www.socscistatistics.com/tests/mannwhitney/default2.aspx 

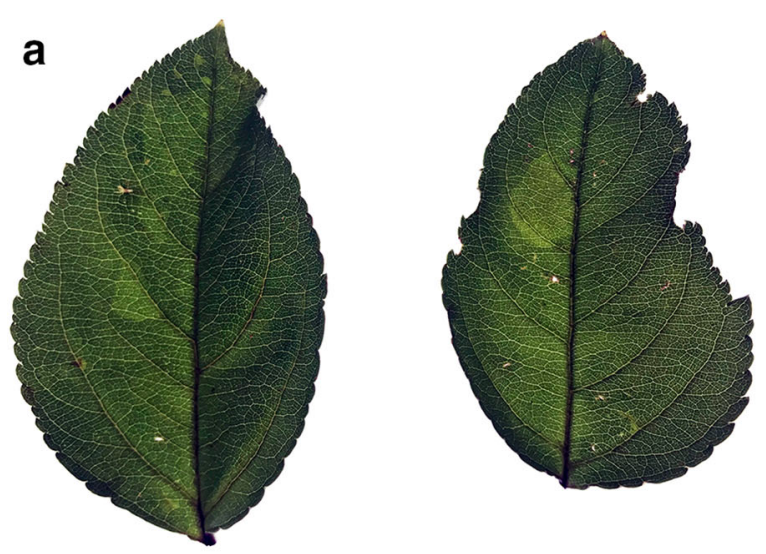

b
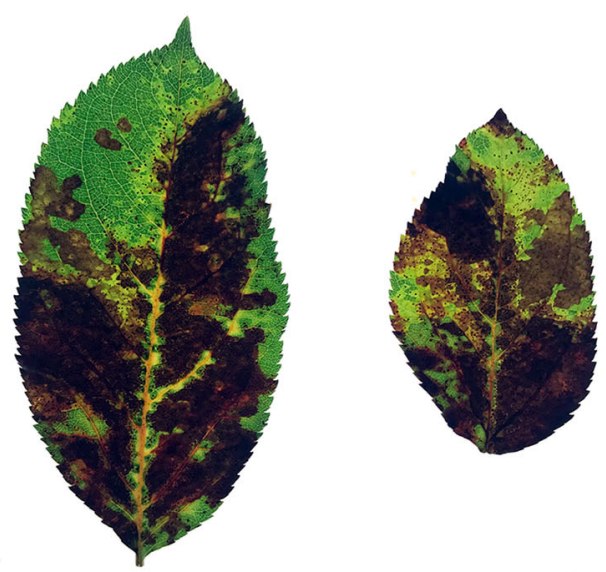

Fig. 4 Leaves of (a) M. prunifolia accession MAL0175 and (b) M. $\times$ domestica 'Golden Delicious' 14 days post inoculation with D. coronariae spores

using transcriptomic approaches (Feng et al. 2019; Li et al. 2014; Xu et al. 2015). Although, no monogenic resistance

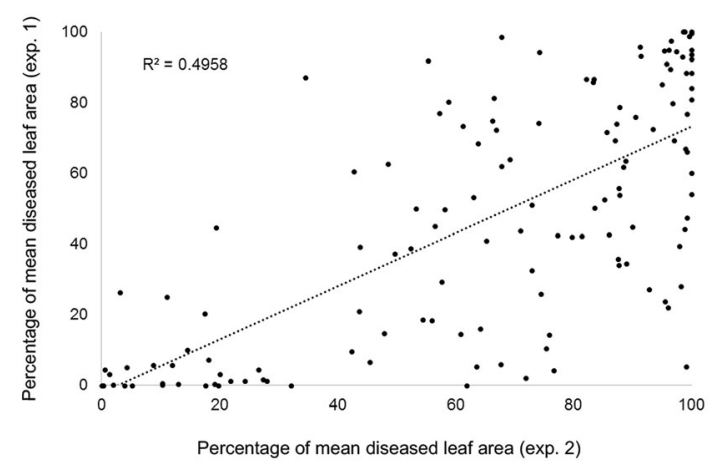

Fig. 5 Correlation of mean percentage of diseased leaf area between inoculation experiment $1 \& 2$. The correlation coefficient obtained was $\rho=0,71$ against $D$. coronariae has been identified yet, recent study of Feng et al. (2019) indicate the existence of quantitative resistance. Feng et al. (2019) described the resistance of Malus baccata to D. coronariae. Interestingly, M. baccata is one of the accessions found to be highly resistant in the current study. Although, the resistant accessions found in our study would require further investigations, they present clear evidence of resistance to apple blotch and pave the way for future genetic mapping studies.

Supplementary Information The online version contains supplementary material available at https://doi.org/10.1007/s10658020-02156-w.

Funding Open Access funding enabled and organized by Projekt DEAL.

Data availability The data supporting the findings of this study are deposited into the Open Agrar repository (Wöhner et al. 2020, https://doi.org/10.5073/20201002-102537).

\section{Compliance with ethical standards}

Ethics declarations The authors declare that ethical standards have been followed and that no human participants or animals were involved in this research.

Competing interests The authors declare that they have no competing interests.

Open Access This article is licensed under a Creative Commons Attribution 4.0 International License, which permits use, sharing, adaptation, distribution and reproduction in any medium or format, as long as you give appropriate credit to the original author(s) and the source, provide a link to the Creative Commons licence, and indicate if changes were made. The images or other third party material in this article are included in the article's Creative Commons licence, unless indicated otherwise in a credit line to the material. If material is not included in the article's Creative Commons licence and your intended use is not permitted by statutory regulation or exceeds the permitted use, you will need to obtain permission directly from the copyright holder. To view a copy of this licence, visit http://creativecommons.org/licenses/by/4.0/.

\section{References}

Aldwinckle, H. S., Forsline, P. L., Gustafson, H. L., \& Hokanson, S. C. (1997). Evaluation of apple scab resistance of Malus sieversii populations from Central Asia. HortScience, 32(3), 440A-4440A.

Crous, P. W., Wingfield, M. J., Schumacher, R. K., Akulov, A., Bulgakov, T. S., Carnegie, A. J., Jurjević, Ž., Decock, C., Denman, S., Lombard, L., Lawrence, D. P., Stack, A. J., Gordon, T. R., Bostock, R. M., Burgess, T., Summerell, B. A., Taylor, P. W. J., Edwards, J., Hou, L. W., Cai, L., 
Rossman, A. Y., Wöhner, T., Allen, W. C., Castlebury, L. A., Visagie, C. M., \& Groenewald, J. Z. (2020). New and interesting fungi. 3. Fungal Systematics and Evolution, 6, 157231. https://doi.org/10.3114/fuse.2020.06.09.

Dang, J. L., Gleason, M. L., Niu, C. K., Liu, X., Guo, Y. Z., Zhang, R., \& Sun, G. Y. (2017). Effects of fungicides and spray application interval on controlling Marssonina blotch of apple in the loess plateau region of China. Plant Disease, 101(4), 568-575.

Dayton, D. F., Bell, R. L., \& Williams, E. B. (1983). Disease resistance (pp. 189-215). West Lafayette, Indiana, USA: Methods in fruit breeding. Purdue University Press.

FAOSTAT (2020). Crops. http://www.fao.org/faostat/en/\#data/QC. Accessed 2 Oct 2020.

Feng, H., Li, H., Zhang, M., Song, Y., Yuan, G., Han, Q., \& Huang, L. (2019). Responses of Fuji (Malus domestica) and Shandingzi (Malus baccata) apples to Marssonina coronaria infection revealed by comparative transcriptome analysis. Physiological and Molecular Plant Pathology, 106, 87-95.

Forsline, P. L., Aldwinckle, H. S., Dickson, E. E., Luby, J. J., \& Hokanson, S. C. (2003). Collection, maintenance, characterization, and utilization of wild apples of Central Asia. Horticultural Reviews-Westport Then New York, 29, 1-62.

Hanke, M. V., Flachowsky, H., Peil, A., \& Emeriewen, O. F. (2020). 19.3 Malus x domestica apple. Biotechnology of Fruit and Nut Crops, 440.

Höfer, M., Ali, M. A. M. S.E., Sellmann, J., \& Peil, A. (2014). Phenotypic evaluation and characterization of a collection of Malus species. Genetic Resources and Crop Evolution, 61(5), 943-964.

Jarolmasjed, S., Sankaran, S., Marzougui, A., Kostick, S., Si, Y., Quirós Vargas, J. J., \& Evans, K. (2019). High-throughput phenotyping of fire blight disease symptoms using sensing techniques in apple. Frontiers in Plant Science, 10, 576.

Kellerhals, M., Szalatnay, D., Hunziker, K., Duffy, B., Nybom, H., Ahmadi-Afzadi, M., Höfer, M., Richter, K., \& Lateur, M. (2012). European pome fruit genetic resources evaluated for disease resistance. Trees, 26, 179-189. https://doi. org/10.1007/s00468-011-0660-9.

Li, Y., Hirst, P. M., Wan, Y., Liu, Y., Zhou, Q., Gao, H., Guo, Y., Zhao, Z., Wang, L., \& Han, M. (2012). Resistance to Marssonina coronaria and Alternaria alternata apple pathotype in the major apple cultivars and rootstocks used in China. HortScience, 47(9), 1241-1244.

Li, M., Xu, J., Qiu, Z., Zhang, J., Ma, F., \& Zhang, J. (2014). Screening and identification of resistance related proteins from apple leaves inoculated with Marssonina coronaria (Ell. \& J.J. Davis). Proteome Science, 12(7), 1-17.

Li, Y., Hu, X. L., Trigiano, R. N., Aldwinckle, H., \& Cheng, Z. M. M. (2019). Evaluation of 110 apple cultivars for resistance to Alternaria blotch caused by Alternaria alternata apple Pathotype. HortScience, 54(8), 1268-1274.

Peil, A., Emeriewen, O. F., Khan, A., Kostik, S., \& Malnoy, M. (2020). Status of fire blight resistance breeding in Malus. Journal of Plant Pathology, 1-10. https://doi.org/10.1007 /s42161-020-00581-8.

Pethybridge, S. J., \& Nelson, S. C. (2015). Leaf doctor: A new portable application for quantifying plant disease severity. Plant Disease, 99(10), 1310-1316.
Prell, H. H., \& Day, P. (2001). Plant-fungal pathogen interaction: A classical and molecular view. Springer Science \& Business Media.

Robinson, J. P., Harris, S. A., \& Juniper, B. E. (2001). Taxonomy of the genus Malus mill.(Rosaceae) with emphasis on the cultivated apple, Malus domestica Borkh. Plant Systematics and Evolution, 226(1-2), 35-58.

Sharma, U., Kaith, N. S., \& Gupta, B. (2018). Management of premature leaf fall in apple by using different combination of fungicides. Journal of Krishi Vigyan, 6(2), 259-261.

Stewart, E. L., \& McDonald, B. A. (2014). Measuring quantitative virulence in the wheat pathogen Zymoseptoria tritici using high-throughput automated image analysis. Phytopathology, 104(9), 985-992.

Sutton, T. B., Aldwinckle, H. S., Agnello, A. M., \& Walgenbach, J. F. (2014). Compendium of apple and pear diseases and pests, Second Edition. APS Press, 1, 48-49.

Surke, M., Heidenreich, M. \& Goldberg, V. (2013). Erstellung von Windrosen im Rahmen von KLAPS. Sächsisches Landesamt für Umwelt, Landwirtschaft und Geologie (LfULG), 1-34. https://publikationen.sachsen.de/bdb/

Wang, G., Sun, Y., \& Wang, J. (2017). Automatic image-based plant disease severity estimation using deep learning. Computational intelligence and neuroscience, 1-8. https://doi.org/10.1155/2017/2917536.

Wöhner, T. (2015). Marssonina coronaria (Ellis \& Davis) Davis (teleomorph Diplocarpon mali Harada Y. Harada \& Sawamura 1974). Erreger des frühzeitigen Blattfalls an Apfel. JKI Datenblätter. Pflanzenkrankheiten und Diagnose, 2, 1-14. https://doi.org/10.5073/jkidpp.2015.002.

Wöhner, T., \& Emeriewen, O. F. (2019). Apple blotch disease (Marssonina coronaria (Ellis \& Davis) Davis)-review and research prospects. European Journal of Plant Pathology, 153(3), 657-669.

Wöhner, T., Girichev, V., Radatz, S., Lauria-Baca, B., Scheinpflug, H., \& Hanke, M. V. (2019). Evaluation of Malus gene bank resources with German strains of Marssonina coronaria using a greenhouse-based screening method. European Journal of Plant Pathology, 153(3), 743-757.

Wöhner, T., Höfer, M., \& Emeriewen, O. F. (2020). Dataset from the evaluation of resistance/susceptibility of Malus genetic resources to apple blotch disease (Diplocarpon coronariae). OpenAgrar Repository. https://doi.org/10.5073/20201002-102537.

Xu, J., Li, M., Jiao, P., Tao, H., Wie, N., Ma, F., \& Zhang, J. (2015). Dynamic transcription profiles of 'Qinguan' apple (Malus $\times$ domestica) leaves in response to Marssonina coronaria inoculation. Frontiers in Plant Science, 6(842), 1-11.

Yin, L., Li, M., Ke, X., Li, C., Zou, Y., Liang, D., \& Ma, F. (2013a). Evaluation of Malus germplasm resistance to marssonina apple blotch. European Journal of Plant Pathology, 136(3), 597-602.

Yin, L., Wang, P., Li, M., Ke, X., Li, C., Liang, D., Wu, S., Ma, X., Li, C., Zou, Y., \& Ma, F. (2013b). Exogenous melatonin improves Malus resistance to Marssonina apple blotch. Journal of Pineal Research, 54, 426-434. https://doi.org/10.1111/jpi.12244.

Zhou, Q., Gao, H., Wang, M., Xu, Y., Guo, Y. Z., Wan, Y. Z., \& Zhao, Z. Y. (2012). Characterization of defence related genes in the 'Qinguan' apple in response to Marssonina coronaria. South African Journal of Botany, 80, 36-43. 